\title{
TNF- $\alpha$ acutely upregulates amylin expression in murine pancreatic beta cells
}

\author{
K. Cai • D. Qi • O. Wang • J. Chen $\cdot$ X. Liu $\cdot$ B. Deng $\cdot$ \\ L. Qian $\cdot$ X. Liu $\cdot$ Y. Le
}

Received: 30 June 2010 / Accepted: 22 October 2010 /Published online: 30 November 2010

(C) Springer-Verlag 2010

\begin{abstract}
Aims/hypothesis Amylin, a secretory protein mainly produced by pancreatic beta cells, is elevated in the circulation of patients with diseases related to acute and chronic inflammation, including acute pancreatitis, pancreas graft rejection, obesity and insulin resistance. TNF- $\alpha$ is involved in these disorders. We investigated the effect of TNF- $\alpha$ on amylin levels and the underlying mechanisms, using murine pancreatic beta cell line MIN6 and pancreatic islets.

Methods Amylin, proinsulin and prohormone convertase 1/3, 2 (Pc1/3, Pc2 [also known as Pcsk1/3 and Pcsk2, respectively]) mRNA levels, and amylin promoter and nuclear factor $\mathrm{kB}(\mathrm{NF}-\mathrm{kB})$ activation were examined by real-time PCR and luciferase reporter assay, respectively. Amylin protein level and mitogen-activated protein kinase phosphorylation were detected by western blot. Activator protein 1 (AP1) activation was examined by electrophoretic mobility shift assay (EMSA).
\end{abstract}

Electronic supplementary material The online version of this article (doi:10.1007/s00125-010-1972-9) contains supplementary material, which is available to authorised users.

K. Cai • D. Qi $\cdot$ O. Wang $\cdot$ J. Chen $\cdot$ X. Liu $\cdot$ B. Deng $\cdot$ L. Qian $\cdot$

Y. Le $(\bowtie)$

Key Laboratory of Nutrition and Metabolism, Institute for Nutritional Sciences,

Shanghai Institutes for Biological Sciences,

and the Graduate School of the Chinese Academy of Sciences,

Shanghai, People's Republic of China

e-mail: yyle@sibs.ac.cn

X. Liu

Laboratory of Molecular Cell Biology,

Institute of Biochemistry and Cell Biology,

Shanghai Institutes for Biological Sciences,

Chinese Academy of Sciences,

Shanghai, People's Republic of China
Results TNF- $\alpha$ acutely induced amylin expression at the transcriptional level and increased proamylin and the intermediate form of amylin in MIN6 cells and islets. However, it had no effect on proinsulin, $P c 1 / 3$ and $P c 2$ expression. Studies with (1) MIN6 cells treated with inhibitors of MEK1/2, c-Jun-N-terminal kinase (JNK) or protein kinase $\mathrm{C} \zeta\left(\mathrm{PKC}_{\zeta}\right)$, (2) MIN6 cells expressing a c-Jun-dominant negative construct and (3) islets from Fos knockout mice demonstrated that TNF- $\alpha$ induced amylin expression through the $\mathrm{PKC}_{\zeta}$-extracellular signal-regulated kinase $(\mathrm{ERK}) / \mathrm{JNK}$ pathways. EMSA showed that $\mathrm{PKC}_{\zeta}$, JNK and ERK1/2 were involved in TNF- $\alpha$-induced AP1 activation, suggesting that TNF- $\alpha$ induces murine amylin expression through the $\mathrm{PKC}_{\zeta}-\mathrm{ERK} 1 / 2-\mathrm{AP} 1$ and $\mathrm{PKC}_{\zeta}-$ JNK - AP1 pathways. Further studies showed that TNF- $\alpha$ also induced murine amylin expression through the phosphatidylinositol 3 kinase-NF- $\mathrm{kB}$ signalling pathway and enhanced human amylin promoter activation through $\mathrm{NF}-\mathrm{KB}$ and AP1.

Conclusions/interpretation TNF- $\alpha$ acutely induces amylin gene expression in beta cells through multiple signalling pathways, possibly contributing to amylin elevation in acute inflammation-related pancreatic disorders.

Keywords Amylin · Beta cell · Gene expression · Islet amyloid polypeptide $\cdot$ Pancreatic islet $\cdot$ Signalling transduction $\cdot$ TNF- $\alpha$

$\begin{array}{ll}\text { Abbreviations } \\ \text { AP1 } & \text { Activator protein 1 } \\ \text { EMSA } & \text { Electrophoretic mobility shift assay } \\ \text { Nfkbia-DN } & \text { Nfkbia dominant-negative construct } \\ \text { JNK } & \text { c-Jun-N-terminal kinase } \\ \text { c-Jun DN } & \text { c-Jun dominant-negative construct } \\ \text { MAPK } & \text { Mitogen-activated protein kinase }\end{array}$




$\begin{array}{ll}\text { MEK } & \text { Mitogen-activated protein kinase kinase } \\ \mathrm{Myr}-\mathrm{PKC}_{\zeta} & \text { Protein kinase } \mathrm{C}_{\zeta} \text { pseudosubstrate } \\ \mathrm{NF}-\kappa \mathrm{B} & \text { Nuclear factor } \mathrm{\kappa B} \\ N F-\kappa B \text {-Luc } & \text { NF- } \mathrm{BB} \text { luciferase reporter construct } \\ \mathrm{PC} & \text { Prohormone convertase } \\ \mathrm{PDX}-1 & \text { Pancreatic and duodenal homeobox 1 } \\ \mathrm{PI} \text { K } & \text { Phosphatidylinositol 3 kinase } \\ \text { PKC } & \text { Protein kinase C }\end{array}$

\section{Introduction}

Amylin, also known as islet amyloid polypeptide (IAPP), is a normal secretory protein mainly expressed by pancreatic beta cells. It plays important roles in energy homeostasis, bone growth and brain development [1-3]. Amylin was discovered in 1987 as a major component of amyloid deposits in the pancreas of type 2 diabetes patients $[4,5]$. Elevated circulating levels of amylin have been detected in patients with severe acute pancreatitis [6], pancreas transplantation [7], obesity and insulin resistance [8-10]. Pancreatic amylin mRNA and plasma amylin levels are also elevated in genetically obese, insulin-resistant rats [11]. However, the mechanisms underlying amylin expression are not completely understood.

TNF- $\alpha$ is a critical player in the inflammatory response in acute pancreatitis [12] and has been reported to be involved in pancreas graft dysfunction [13]. Circulating TNF- $\alpha$ is increased in obesity [14] and has been implicated as a causative factor in obesity-associated insulin resistance and the pathogenesis of type 2 diabetes $[15,16]$. In this study, we used the cultured murine pancreatic beta cell line MIN6 and pancreatic islets, as well as human amylin promoter luciferase reporter constructs, to examine the effect of TNF- $\alpha$ on amylin expression and further explore the mechanisms involved.

\section{Methods}

Materials TNF- $\alpha$ was purchased from Peprotech (Rocky Hill, NJ, USA). PD98059, SP600125, protein kinase Ch $\left(\mathrm{PKC}_{\zeta}\right)$ pseudosubstrate $\left(\mathrm{Myr}-\mathrm{PKC}_{\zeta}\right)$, wortmannin, sulfasalazine and pyrrolidine dithiocarbamate were from Calbiochem (La Jolla, CA, USA). Ficoll 400 was purchased from Amersham Pharmacia Biotech (Piscataway, NJ, USA). DMEM was from Gibco BRL (Burlington, ON, Canada). Lipofectamine 2000 was from Invitrogen (Carlsbad, CA, USA). Unless otherwise stated, all other reagents were purchased from Sigma Aldrich (St Louis, MO, USA).

Pancreatic islet preparation and cell culture Pancreatic islets were isolated from C57/B6 mice (Shanghai SLAC
Laboratory Animal Company, Shanghai, China) or Fos knockout mice [17] by type $\mathrm{V}$ collagenase digestion followed by Ficoll 400 gradient separation, as described previously [18]. Islets were cultured in DMEM containing $5.6 \mathrm{mmol} / 1$ glucose, $10 \%$ FBS (vol./vol.), $100 \mathrm{U} / \mathrm{ml}$ penicillin and $100 \mu \mathrm{g} / \mathrm{ml}$ streptomycin (Bio Basis, Markham, ON, Canada). All experiments using animals were in accordance with the 'Principles of laboratory animal care' (NIH publication no. 85-23, revised 1985; http://grants1. nih.gov/grants/olaw/references/phspol.htm) and were approved by the Biological Research Ethics Committee, Institute for Nutritional Sciences, Chinese Academy of Sciences. MIN6 cells were cultured at $37^{\circ} \mathrm{C}$ in DMEM containing $5.6 \mathrm{mmol} / \mathrm{l}$ glucose, $10 \% \mathrm{FBS}$ and antibiotics in a humidified atmosphere with $5 \% \mathrm{CO}_{2}$.

$R N A$ extraction and real-time PCR Total RNA was extracted from MIN6 cells or mouse pancreatic islets using the Trizol reagent (Invitrogen, Carlsbad, CA, USA) and depleted of contaminating DNA with RNase-free DNase (TAKARA Biotechnology, Otsu, Shiga, Japan). cDNA was synthesised from $2 \mu \mathrm{g}$ RNA with M-MuLV reverse transcriptase (Fermentas, Burlington, ON, Canada) and random hexamer. Reverse-transcribed cDNA in triplicate samples was checked for amylin, proinsulin 1, proinsulin 2, prohormone convertase 1/3 ( $P c 1 / 3$ [also known as $P c s k 1 / 3$ ]) or $P c 2$ (also known as Pcsk2) mRNA expression by quantitative real-time PCR with Power SYBR Green PCR master Mix (Applied Biosystems, Warrington, UK) on a sequence detector (ABI Prism 7500; Applied Biosystems, Foster City, CA, USA). The primers for real-time PCR are listed in Electronic supplementary material (ESM) Table 1. Amplification of the target cDNA was normalised to $\beta$-actin expression. Relative levels of target mRNA expression were calculated using the $2^{-\Delta \Delta \mathrm{C}_{\mathrm{t}}}$ method.

Western blotting MIN6 cells were stabilised in KRB buffer for $2 \mathrm{~h}$ followed by stimulation with TNF- $\alpha$ for $5 \mathrm{~min}$. Phosphorylation of ERK1/2 or c-Jun-N-terminal kinase (JNK) was examined by western blot as previously described [19]. Levels of ERK1/2 or JNK were also examined to ensure equal loading. Amylin protein levels in murine islets were examined by western blot with anti-rat amylin antiserum (T-4145; Peninsula Laboratory, Belmont, CA, USA) as previously described [20].

Plasmid construction and luciferase reporter assay The human amylin promoter fragments between -222 and 450 , and -391 and 450 of the transcriptional start site of amylin gene [21] were amplified by PCR and cloned into the pGL3-basic luciferase reporter plasmid (Promega, Madison, WI, USA) between the MIuI and XhoI sites. The constructs were named $-222 / 450$ and $-391 / 450$, respectively, and 
confirmed by restriction enzyme digestion as well as sequencing. Amylin promoter luciferase plasmid was cotransfected with the pRL-TK Renilla plasmid into MIN6 cells with a 40:1 ratio using Lipofectamine 2000. At $36 \mathrm{~h}$ after the transfection, cells were cultured for another $8 \mathrm{~h}$ in DMEM containing $0.5 \mathrm{mmol} / 1$ glucose and 2\% FBS (vol./vol.), with or without $2.8 \mathrm{nmol} / 1 \mathrm{TNF}-\alpha$. Luciferase activities of the promoter construct and the pRL-TK construct were measured sequentially using a reporter system (Dual-Luciferase Reporter Assay; Promega). Variation in transfection efficiency was normalised by dividing the promoter construct activity by the respective co-transfected pRL-TK luciferase activity.

For nuclear factor $\kappa \mathrm{B}(\mathrm{NF}-\kappa \mathrm{B})$-dependent luciferase reporter assay, $5 \times \mathrm{NF}-\mathrm{kB}$ luciferase reporter construct $(N F-\kappa B$-Luc) was co-transfected with pRL-TK Renilla plasmid into the MIN6 cells using Lipofectamine 2000 as described above. At $36 \mathrm{~h}$ after the transfection, cells were treated for $1 \mathrm{~h}$ with or without various inhibitors, followed by stimulation with TNF- $\alpha$ for an additional $6 \mathrm{~h}$. Luciferase activities were detected and normalised as above.

Electrophoretic mobility shift assay MIN6 cells were cultured for $12 \mathrm{~h}$ in medium without FBS, then treated for $1 \mathrm{~h}$ with or without various inhibitors, followed by treatment with $2.8 \mathrm{nmol} / 1 \mathrm{TNF}-\alpha$ for another $2 \mathrm{~h}$. The nuclear extracts were prepared and electrophoretic mobility shift assay (EMSA) was performed with a kit (LightShift Chemiluminescent EMSA kit; Pierce Chemical, Rockford, IL, USA) as previously described [22]. The oligonucleotide sequences of activator protein 1 (AP1) probes were: amylin AP1 probe: 5'-AAGAGCTTGAGTCACACAAGA-3'; consensus AP1 probe: 5'-CGCTTGATGACTCAGCCGGAA-3'.

Statistical analysis Results are expressed as means \pm SD. Statistical analysis was performed using ANOVA for time course and dose-response, and Student's $t$ test for other data.

\section{Results}

TNF- $\alpha$ induces murine amylin expression To determine the effect of TNF- $\alpha$ on amylin gene expression, MIN6 cells were challenged with different concentrations of TNF- $\alpha$ for different lengths of time and the mRNA expression of amylin were detected by quantitative real-time PCR. As shown in Fig. 1a, b, MIN6 cells cultured in DMEM containing $5.6 \mathrm{mmol} / \mathrm{l}$ glucose expressed transcripts for amylin. This expression was significantly enhanced by TNF- $\alpha$ in time- and dose-dependent manners. The minimal concentration of $\mathrm{TNF}-\alpha$ needed to significantly induce amylin gene expression was $0.57 \mathrm{nmol} / 1$. Consistent with the results obtained from MIN6 cells, mRNA expression of amylin in murine pancreatic islets was significantly enhanced by TNF- $\alpha$ after $9 \mathrm{~h}$ of stimulation (Fig. 1c). Interestingly, the inductive effect of $\mathrm{TNF}-\alpha$ on amylin mRNA was more potent in islets than in MIN6 cells, suggesting that amylin expression in response to TNF- $\alpha$ is more sensitive in islets than in transformed beta cells. As amylin and insulin are co-localised in beta cells and cosecreted in response to glucose [23], we then examined the effect of TNF- $\alpha$ on proinsulin expression in MIN6 cells. While TNF- $\alpha$ upregulated amylin mRNA levels in MIN6 cells and murine primary islets in a time-dependent manner (Fig. 1a, ESM Fig. 1), it had no effect on proinsulin 1 and proinsulin 2 mRNA expressions in MIN6 cells (Fig. 1d) and islets (ESM Fig. 1), suggesting that TNF- $\alpha$ specifically induces amylin expression in beta cells. We checked the effect of TNF- $\alpha$ on cytokine expression in MIN6 cells and found that 3 to $15 \mathrm{~h}$ of TNF- $\alpha$ treatment at $2.87 \mathrm{nmol} / 1 \mathrm{had}$ no effect on $I l 1 \beta$ (also known as $I l 1 b$ ), Il6 or $M c p-1$ (also known as $C$ cl2) mRNA expression (data not shown). These results suggest that the inductive effect of TNF- $\alpha$ on amylin expression was not indirectly mediated by cytokines induced by TNF- $\alpha$.

To determine the effect of TNF- $\alpha$ on amylin mRNA stability, MIN6 cells pretreated for $9 \mathrm{~h}$ with or without $2.87 \mathrm{nmol} / 1 \mathrm{TNF}-\alpha$ were cultured with $5 \mu \mathrm{g} / \mathrm{ml}$ actinomycin D for 2, 5 and $7 \mathrm{~h}$, after which amylin mRNA levels were examined by real-time PCR. Although TNF- $\alpha$ markedly increased amylin mRNA expression, there was no significant difference in the curves of mRNA decay between TNF- $\alpha$-treated and control groups (Fig. 1e), suggesting that TNF- $\alpha$ increased amylin expression at the transcriptional level.

We next examined the effect of TNF- $\alpha$ on amylin protein production. Western blot assay showed that in the resting state, mature amylin is the main form of amylin in murine pancreatic islets. Stimulation of murine islets with $2.87 \mathrm{nmol} / 1 \mathrm{TNF}-\alpha$ or $16 \mathrm{mmol} / 1$ glucose for $24 \mathrm{~h}$ significantly increased levels of proamylin $(\sim 8 \mathrm{kDa})$ and the intermediate form of amylin ( $\sim 6 \mathrm{kDa})$ (Fig. 2a, b). TNF- $\alpha$ had no significant effect on the expression of $P c 1 / 3$ or Pc2 (Fig. 2c), which are responsible for proamylin processing [24]. These results might explain the increase of proamylin and the intermediate form of amylin by TNF- $\alpha$ stimulation.

The $P K C_{\zeta}-E R K 1 / 2-A P 1$ and $P K C_{\zeta}-J N K-A P 1$ pathways are involved in TNF- $\alpha$-induced amylin gene expression It has been reported that the biological effects of $\mathrm{TNF}-\alpha$ are mediated through mitogen-activated protein kinase (MAPK) pathways [25]. We observed that pretreatment of MIN6 cells with PD98059, a MEK 1/2 inhibitor, or with SP600125, an inhibitor of JNK, inhibited TNF- $\alpha$ - 

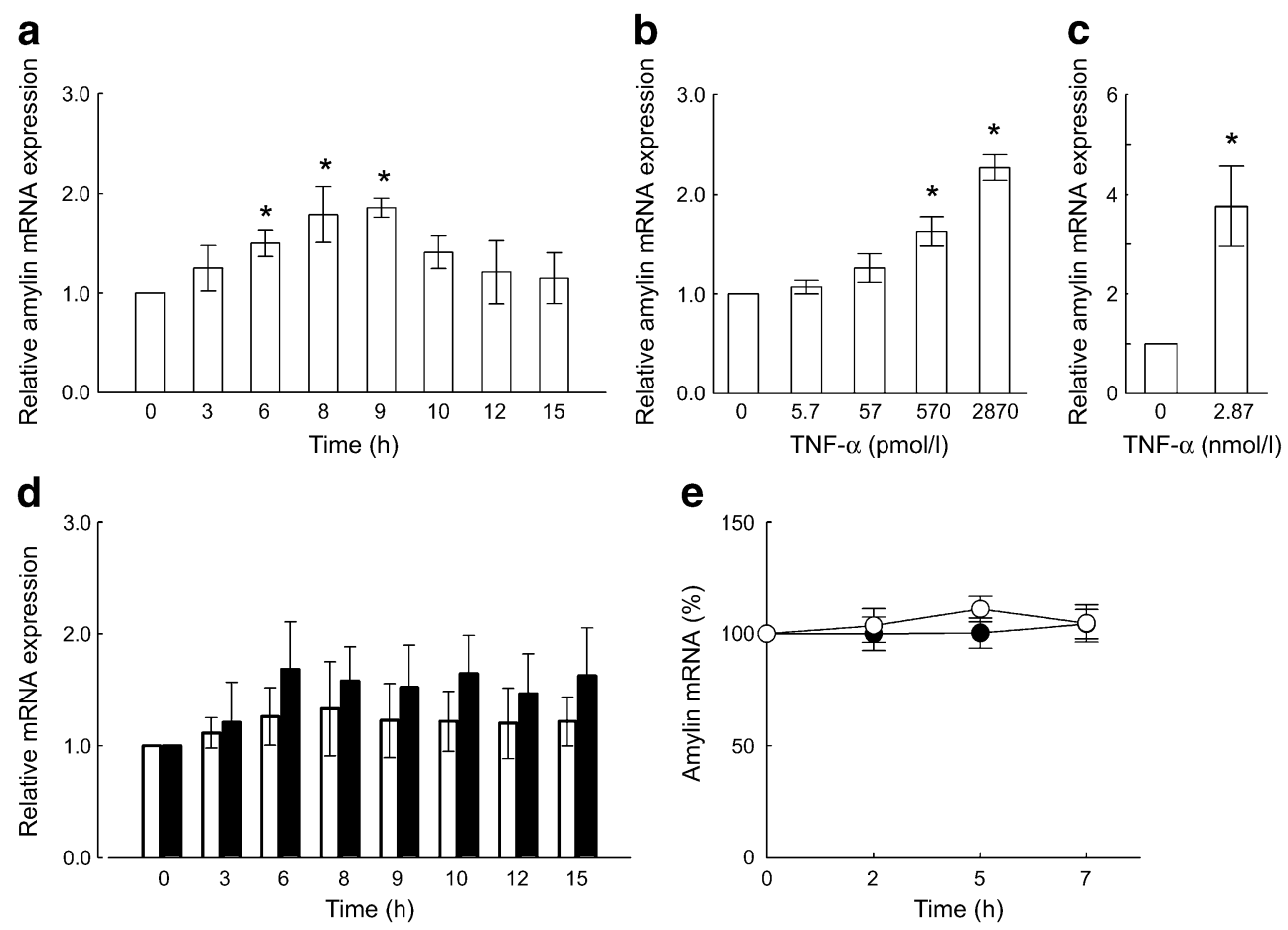

Fig. 1 TNF- $\alpha$ upregulates amylin gene expression. MIN6 cells were incubated with $2.87 \mathrm{nmol} / 1 \mathrm{TNF}-\alpha$ for different time periods $(\mathbf{a}, \mathbf{d})$ or (b) with different concentrations of TNF- $\alpha$ for $9 \mathrm{~h}$. Total RNA was then extracted and examined for amylin $(\mathbf{a}, \mathbf{b})$ or proinsulin (d) mRNA expression by real-time PCR. White bars, proinsulin 1; black bars, proinsulin 2. c Mouse pancreatic islets were treated with $2.87 \mathrm{nmol} / \mathrm{l} \mathrm{TNF}-\alpha$ for $9 \mathrm{~h}$ and amylin mRNA expression examined

by real-time PCR. e MIN6 cells pretreated with (white circles) or without (control, black circles) $2.87 \mathrm{nmol} / 1 \mathrm{TNF}-\alpha$ for $9 \mathrm{~h}$ were cultured with $5 \mu \mathrm{g} / \mathrm{ml}$ actinomycin D for the indicated time intervals. Amylin mRNA expression was then examined by real-time PCR. All data are shown as mean $\pm \mathrm{SD}$ of three independent experiments. ${ }^{*} p<0.05$ vs MIN6 cells or islets cultured with control medium

induced amylin gene expression (Fig. 3a). PD98059 and SP600125 at the tested concentrations had no effect on cell viability as examined by 3-(4,5-dimethylthiazol-2-yl)-2,5diphenyltetrazolium bromide (MTT) assay (data not shown). These results indicate that TNF- $\alpha$ might upregulate amylin gene expression through activation of signalling pathways related to ERK 1/2 and JNK. As PD98059 and

a

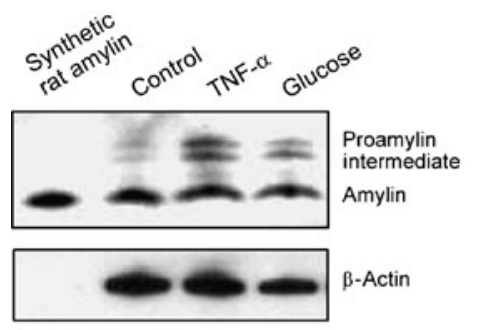

b

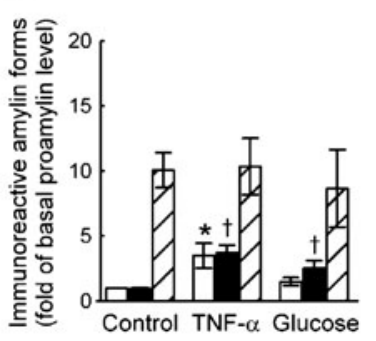

Fig. 2 TNF- $\alpha$ induces amylin protein production. a Murine pancreatic islets were cultured overnight in control medium containing $2.8 \mathrm{mmol} / 1$ glucose, followed by treatment with $2.87 \mathrm{nmol} / 1 \mathrm{TNF}-\alpha$ or $16 \mathrm{mmol} / \mathrm{l}$ glucose for $24 \mathrm{~h}$. Amylin protein levels were examined by western blot assay. A representative gel is shown, in which synthetic rat amylin was used as amylin positive control. b Quantification of blot (a). White bars, proamylin; black bars, intermediate form of

SP600125 have also been reported to inhibit other protein kinases [26], it is possible that protein kinases other than ERK1/2 and JNK may also be involved in amylin upregulation by TNF- $\alpha$.

Protein kinase $\mathrm{C}_{\zeta}$, a member of the atypical PKC family, acts as a signalling molecule of TNF- $\alpha$ and has been shown to induce MAPK activation [27]. We examined

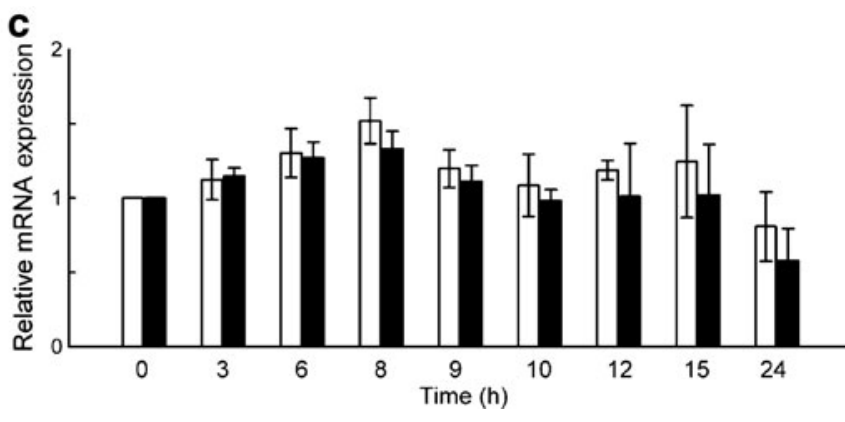

amylin; hatched bars, amylin. ${ }^{*} p<0.05$ vs proamylin in islets cultured with control medium; ${ }^{\dagger} p<0.05$ vs intermediate form of amylin in islets cultured with control medium. c MIN6 cells were incubated with $2.87 \mathrm{nmol} / 1 \mathrm{TNF}-\alpha$ for different time periods, then total RNA was extracted and examined for prohormone convertase $1 / 3$ (white bars) and 2 (black bars) mRNA by real-time PCR. All data are shown as mean $\pm \mathrm{SD}$ of three independent experiments 
a

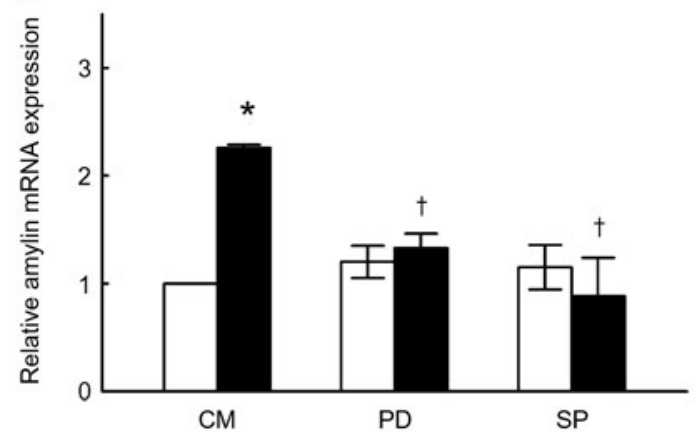

C



b



d

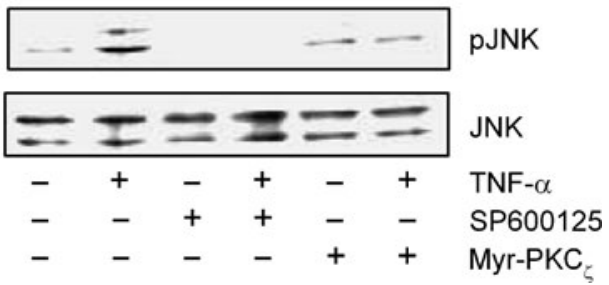

${ }^{*} p<0.05$ vs cells cultured with $\mathrm{CM} ;{ }^{\dagger} p<0.05$ compared with cells treated with TNF- $\alpha$ alone. c, d MIN6 cells pretreated for $2 \mathrm{~h}$ with $2.5 \mu \mathrm{mol} / 1 \mathrm{Myr}-\mathrm{PKC}_{\zeta}, 30 \mu \mathrm{mol} / 1 \mathrm{PD}$ or $50 \mu \mathrm{mol} / 1 \mathrm{SP}$ were stimulated with $2.87 \mathrm{nmol} / 1 \mathrm{TNF}-\alpha$ for $5 \mathrm{~min}$. ERK1/2 (c) or JNK (d) phosphorylation was examined by western blot. The experiments were performed at least three times and representative results are shown

region of murine amylin gene. To examine whether AP1 is involved in TNF- $\alpha$-induced amylin gene expression, we transfected MIN6 cells with a control vector pcDNA 3.1 or a c-Jun dominant-negative construct (c-Jun DN) [29] and found that overexpression of $c-J u n$ DN significantly attenuated TNF- $\alpha$-induced amylin gene expression in MIN6 cells (Fig. 4a ). Transfection of murine primary pancreatic islets with $c$-Jun DN also inhibited the inductive effect of TNF- $\alpha$ on amylin gene expression (Fig. 4b). Further studies showed that TNF- $\alpha$ failed to induce amylin expression in islets isolated from Fos knockout mice (Fig. 4c). These results suggest that AP1, which is composed of c-Jun and c-Fos, plays an essential role in induction of amylin gene expression by TNF- $\alpha$.

We next tested whether AP1 is a transcription factor downstream of $\mathrm{PKC}_{\zeta}-\mathrm{ERK} 1 / 2$ and $\mathrm{PKC}_{\zeta}-\mathrm{JNK}$ signalling, which mediates amylin upregulation by TNF- $\alpha$. EMSA assay with a consensus AP1 probe or an amylin AP1 probe that contains the AP1 binding sequence at the promoter region $(-1574 /-1568)$ of murine amylin gene showed that TNF- $\alpha$ significantly increased the binding activity of AP1 in MIN6 cells (Fig. 5a, b). In TNF- $\alpha$ stimulated cells, excess unlabelled consensus AP1 probe and amylin AP1 probe both competed for consensus AP1 binding, while excess amylin AP1 probe competed for amylin AP1 binding (Fig. 5a), supporting the notion that the existence of a few AP1 binding sites in the promoter 

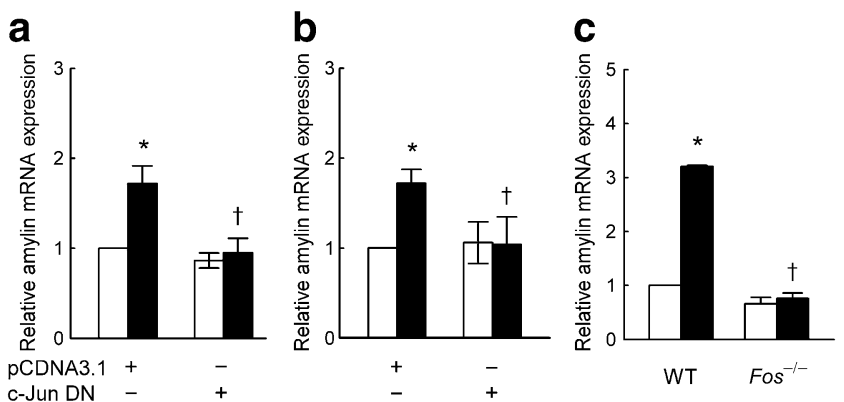

Fig. 4 TNF- $\alpha$ stimulates amylin gene expression through activation of AP1. MIN6 cells (a) or mouse pancreatic islets (b) were transfected for $36 \mathrm{~h}$ with $c$-Jun DN or control vector pCDNA 3.1, then treated with (black bars) or without (control, white bars) $2.87 \mathrm{nmol} / 1 \mathrm{TNF}-\alpha$ for another $9 \mathrm{~h}$. Amylin mRNA expression was examined by real-time PCR. c Mouse pancreatic islets isolated from wild type (WT) or $\mathrm{Fos}^{-1-}$ mice were treated with $2.87 \mathrm{nmol} / 1 \mathrm{TNF}-\alpha$ for $9 \mathrm{~h}$ and amylin mRNA expression examined by real-time PCR. All data are shown as mean \pm $\mathrm{SD}$ of three independent experiments. ${ }^{*} p<0.05$ vs pcDNA3.1-transfected MIN6 cells or islets from WT mice cultured with control medium; ${ }^{\dagger} p<0.05$ vs pcDNA3.1-transfected MIN6 cells or islets from WT mice in response to TNF- $\alpha$

the amyln AP1 probe is specific; moreover, TNF- $\alpha$ induced AP1 binding to the promoter region of amylin gene. The increased amylin AP1 activity induced by TNF- $\alpha$ was significantly inhibited by pretreatment of MIN6 cells with $\mathrm{Myr}^{-\mathrm{PKC}}{ }_{\zeta}, \mathrm{SP} 600125$ or PD98059 (Fig. 5b,c). Taken together, these results suggest that TNF- $\alpha$ induced amylin gene expression in beta cells through the $\mathrm{PKC}_{\zeta}-\mathrm{ERK} 1 / 2-$ $\mathrm{AP} 1$ and $\mathrm{PKC}_{\zeta}-\mathrm{JNK}-\mathrm{AP} 1$ pathways.

$T N F-\alpha$ induces amylin gene expression through pathways related to that of phosphatidylinositol 3- kinase-NF$\kappa B$ Transcription factor NF- $\mathrm{kB}$ is a key component of the TNF- $\alpha$ signal transduction pathway [25]. Phosphatidylinositol 3 kinase (PI3K) has been reported to be an upstream molecule of NF-KB [30]. Thus we checked whether PI3K and NF- $\mathrm{KB}$ were involved in TNF- $\alpha$-induced amylin gene expression in pancreatic beta cells. Pretreatment of MIN6 cells with wortmannin (PI3K inhibitor) or sulfasalazine (NF-KB inhibitor) [31] significantly inhibited TNF- $\alpha-$ induced amylin gene expression (Fig. 6a). Wortmannin and sulfasalazine at the tested concentrations had no effect on cell viability (data not shown). These results suggest that PI3K and NF- $K B$ are involved in amylin upregulation by TNF- $\alpha$. To further confirm that NF- $k B$ activation is involved in the induction of amylin expression by TNF- $\alpha$, we transfected MIN6 cells or mouse pancreatic islets with an Nfkbia dominant-negative construct (Nfkbia-DN) [32] or control vector flag-zeo. Overexpression of Nfkbia-DN in MIN6 cells (Fig. 6b) and islets (Fig. 6c) both significantly attenuated TNF- $\alpha$-induced amylin gene expression, suggesting an essential role of NF- $\mathrm{KB}$ in the upregulation of amylin expression by TNF- $\alpha$.

We next examined whether PI3K is an upstream signalling molecule in NF- $\mathrm{kB}$ activation by TNF- $\alpha$. Compared with MIN6 cells transfected with pGL3-basic plasmid, cells transfected with $N F-\kappa B$-Luc responded to TNF- $\alpha$ with a 5.6-fold increase of luciferase activity. Pretreatment of $N F-\kappa B$-Luc transfected cells with wortmannin and pyrrolidine dithiocarbamate (NF- $\mathrm{KB}$ inhibitor) both significantly inhibited TNF- $\alpha$-induced NF- $\mathrm{KB}$ activation (Fig. 6d), indicating that PI3K mediates NF-KB activation by TNF- $\alpha$ in beta cells. These results suggest that pathways related to that of PI3K-NF- $\mathrm{KB}$ are involved in TNF- $\alpha$-induced amylin gene expression in mouse beta cells.

$T N F-\alpha$ induces human amylin promoter activation through $A P 1$ and $N F-\kappa B$ It has been reported that transcription of a



b

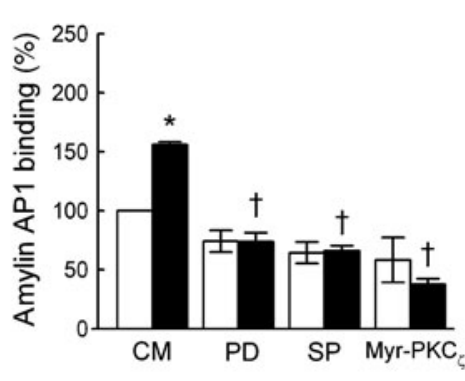

C

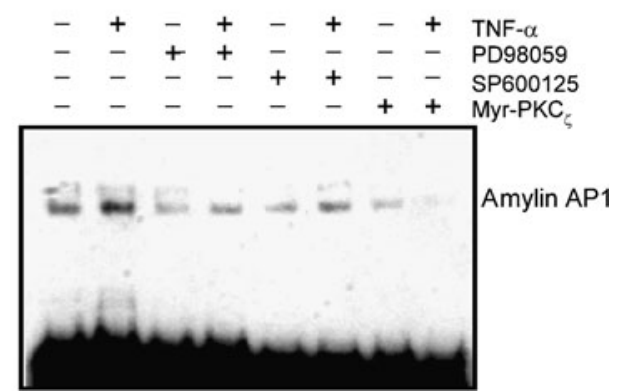

Fig. $5 \mathrm{TNF}-\alpha$ activates AP1 through ERK1/2, JNK and $\mathrm{PKC}_{\zeta}$. a MIN6 cells were treated for $2 \mathrm{~h}$ with or without $2.87 \mathrm{nmol} / 1 \mathrm{TNF}-\alpha$, and the nuclear protein was extracted and applied for EMSA using biotin-labelled amylin AP1 probe (A-AP1 probe) or consensus AP1 probe (C-AP1 probe). As competitor we used 100-fold of unlabelled consensus AP1 probe (cold-C-AP1) or amylin AP1 probe (cold-AAP1). The experiments were performed at least three times and representative results are shown. b MIN6 cells pretreated for $1 \mathrm{~h}$ with control medium (CM), $2.5 \mu \mathrm{mol} / 1 \mathrm{Myr}-\mathrm{PKC}_{\zeta}, 50 \mu \mathrm{mol} / 1 \mathrm{SP} 600125$ (SP) or $30 \mu \mathrm{mol} / 1 \mathrm{PD} 98059$ (PD) were stimulated with (black bars) or without (white bars) $2.87 \mathrm{nmol} / 1 \mathrm{TNF}-\alpha$ for another $2 \mathrm{~h}$. The nuclear protein was extracted and applied for EMSA using biotin-labelled amylin AP1 probe. Values are means \pm SD of three independent experiments; ${ }^{*} p<0.05$ vs cells cultured with $\mathrm{CM} ;{ }^{\dagger} p<0.05$ compared with cells treated with $2.87 \mathrm{nmol} / 1 \mathrm{TNF}-\alpha$ alone. c A representative gel for experiment shown above (b) 

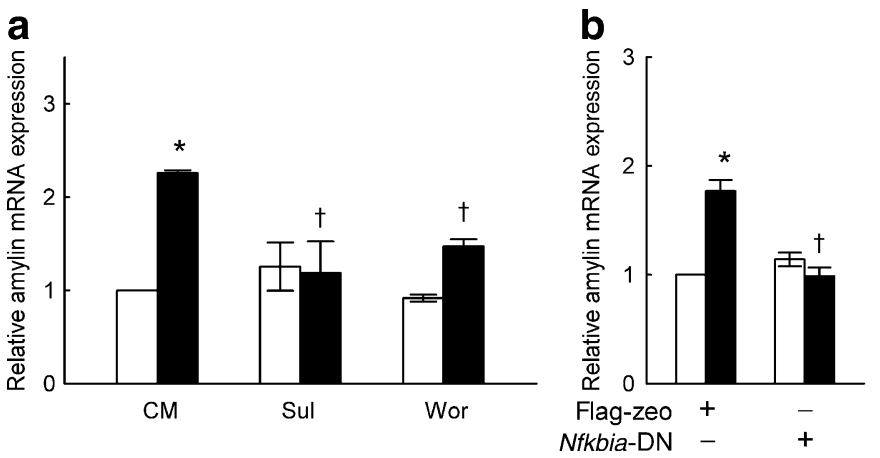

Fig. 6 Involvement of PI3K-NF-kB signalling pathway in TNF$\alpha$-induced amylin gene expression in MIN6 cells and pancreatic islets. a MIN6 cells pretreated for $1 \mathrm{~h}$ with control medium (CM), $50 \mu \mathrm{mol} / 1$ sulfasalazine (Sul) or $100 \mathrm{nmol} / 1$ wortmannin (Wor) were stimulated with (black bars) or without (white bars) $2.87 \mathrm{nmol} / 1 \mathrm{TNF}-\alpha$ for $9 \mathrm{~h}$, then amylin mRNA expression was examined by real-time PCR. ${ }^{*} p<0.05$ vs cells cultured with control medium; $\dagger p<0.05$ compared with cells treated with TNF- $\alpha$ alone. b MIN6 cells or mouse pancreatic islets (c) transiently transfected with $N f k b i a$-DN or control vector flagzeo for $36 \mathrm{~h}$ were treated with control medium (white bars) or $2.87 \mathrm{nmol} / \mathrm{l} \mathrm{TNF}-\alpha$ (black bars) for another $9 \mathrm{~h}$ and amylin mRNA expression was examined by real-time PCR. ${ }^{*} p<0.05$ vs flag-zeo-

human amylin gene is controlled by a promoter region spanning from $-2,798$ to 450 relative to the transcriptional start site. The $-222 / 450$ and $-391 / 450$ sequences have approximately the same transcription activity as the whole promoter region of human amylin [21]. We therefore constructed luciferase reporter plasmids containing these two sequences to test the effect of TNF- $\alpha$ on human amylin gene transcription. Compared with MIN6 cells transfected with pGL-3-basic plasmid, cells transfected with human amylin promoter constructs $-391 / 450$ or $-222 / 450$ both responded to TNF- $\alpha$ (Fig. 7a, b), demonstrating that human amylin gene expression is also enhanced by TNF- $\alpha$.

We analysed transcription factor binding sites in the human amylin promoter region with AliBaba2 software and found that five AP1 and two NF- $\mathrm{KB}$ binding sites were located in the region from -222 to 450 (Table 1). Then we further tested whether AP1 and NF- $\mathrm{KB}$ were also involved in TNF- $\alpha$-induced human amylin expression. Pretreatment of $-222 / 450$ construct-transfected MIN6 cells with curcumin (AP1 inhibitor) [33] or sulfasalazine (NF-kB inhibitor) both significantly inhibited TNF- $\alpha$-induced human amylin promoter activation (Fig. 7c), suggesting that AP1 and NF$\kappa \mathrm{B}$ also mediate TNF- $\alpha$-induced human amylin gene expression.

\section{Discussion}

In the current study, we investigated the effect of TNF- $\alpha$ on amylin gene expression in the mouse pancreatic beta cell line MIN6 and in pancreatic islets. We found that TNF- $\alpha$


transfected cells cultured with control medium; ${ }^{\dagger} p<0.05$ vs flag-zeotransfected cells in response to TNF- $\alpha$. d The pGL3-basic or NF-kBLuc construct was co-transfected with the pRL-TK renilla luciferase reporter plasmid into MIN6 cells. After $36 \mathrm{~h}$, cells were treated with control medium $(\mathrm{CM})$ or medium containing various inhibitors ( $20 \mu \mathrm{mol} / 1$ pyrrolidine dithiocarbamate [PDTC], $100 \mathrm{nmol} / 1$ wortmannin) for $1 \mathrm{~h}$ followed by $2.87 \mathrm{nmol} / 1 \mathrm{TNF}-\alpha$ (black bars; white bars, control) for additional $6 \mathrm{~h}$.. Luciferase activities were measured, normalised to renilla expression of the pRL-TK plasmid and are shown as fold over the activity of the pGL3-basic construct in control medium. ${ }^{*} p<0.05$ vs cells cultured in control medium; ${ }^{\dagger} p<0.05$ vs cells treated with TNF- $\alpha$ alone. All data are shown as mean $\pm \mathrm{SD}$ of three independent experiments

acutely induced amylin expression at mRNA and protein levels, but had no effect on proinsulin expression. We further demonstrated that TNF- $\alpha$ had no effect on amylin mRNA stability and that it enhanced amylin gene expression through pathways related to the $\mathrm{PKC}_{\zeta}-\mathrm{ERK} / \mathrm{JNK}-\mathrm{AP} 1$ and PI3K-NF-KB signalling pathways (Fig. 8). Human amylin gene is also upregulated by TNF- $\alpha$ through activation of AP1 and NF-KB.

Shepherd et al. [34] reported that treatment with TNF- $\alpha$ $(0.57 \mathrm{nmol} / \mathrm{l}, 48 \mathrm{~h})$ had no effect on human amylin gene promoter activity and decreased amylin mRNA level in rat islets. The inconsistent results of human amylin promoter activation by TNF- $\alpha$ in their and our study may be due to different human amylin promoter regions and/or different TNF- $\alpha$ concentrations/treatment times used in the experiments. Our studies on amylin mRNA and protein level as well as amylin mRNA stability all demonstrated that TNF- $\alpha$ could upregulate amylin expression. We also found that when MIN6 cells were stimulated with $0.57 \mathrm{nmol} / 1 \mathrm{TNF}-\alpha$ for up to $48 \mathrm{~h}$, amylin mRNA level was robustly increased after $9 \mathrm{~h}$ stimulation followed by a gradual recovery to basal level (ESM Fig. 2). All these results show that TNF$\alpha$ acutely induces murine amylin gene expression and promotes human amylin transcription.

Increased circulating levels of TNF- $\alpha$ and amylin have been detected in obese and insulin-resistant human patients $[8-10,14,35]$. Plasma level of amylin or TNF- $\alpha$ is also elevated in genetically obese, insulin-resistant animal models [11, 35]. Although we didn't observe inductive effects of TNF- $\alpha$ on amylin expression after prolonged treatment of MIN6 cells with TNF- $\alpha$ for up to $48 \mathrm{~h}, \mathrm{TNF}-\alpha$ 

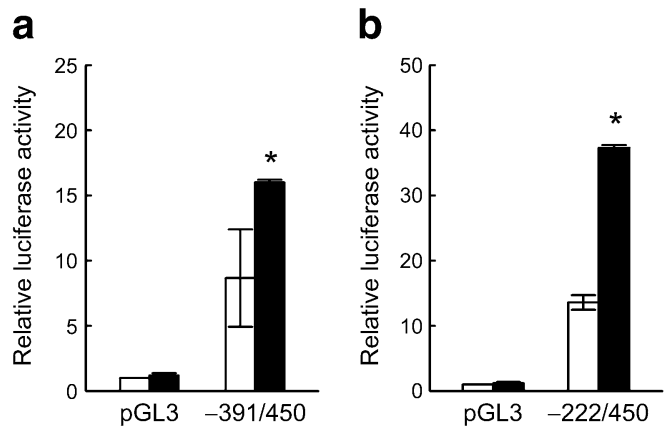

Fig. 7 TNF- $\alpha$ activates human amylin promoter through AP1 and NF-kB. a, The pGL3-basic vector (pGL3) or human amylin promoter luciferase constructs, $-391 / 450$ and (b) $-222 / 450$, was co-transfected with the pRL-TK renilla luciferase reporter plasmid into MIN6 cells. After $36 \mathrm{~h}$, the cells were stimulated with $2.87 \mathrm{nmol} / 1 \mathrm{TNF}-\alpha$ (black bars; control, white bars) and luciferase activities were measured $8 \mathrm{~h}$ later. c MIN6 cells transfected with $-222 / 450$ construct were incubated for $1 \mathrm{~h}$ with control medium (CM), $10 \mu \mathrm{mol} / 1$ curcumin

may nevertheless induce amylin expression under acute inflammation-related conditions. Elevation of plasma amylin concentration was observed in severe acute pancreatitis [6]. Although amylin may be increased as a consequence of islet cell necrosis, it may also be induced by TNF- $\alpha$, which plays an important role in the inflammatory response in pancreatitis. In islet transplantation, TNF- $\alpha$ has been shown to be produced locally by macrophages from the recipient and the donor [36, 37]. The elevation of amylin in the circulation of patients with islet transplantation may result from amylin upregulation by TNF- $\alpha$, but needs further investigation.

Using a series of biochemical and molecular biology methods with specific inhibitors of $\mathrm{PKC}_{\zeta}$, MAPK, PI3K and NF- $\mathrm{KB}$, with dominant-negative constructs for c-Jun and Nfkbia, and with islets from Fos knockout mice, we demonstrated that TNF- $\alpha$-induced amylin expression in murine pancreatic beta cells through the $\mathrm{PKC}_{\zeta}-\mathrm{JNK}-\mathrm{AP} 1, \mathrm{PKC}_{\zeta}-\mathrm{ERK} 1 / 2-\mathrm{AP} 1$ and PI3K-NF-

Table 1 Putative transcriptional factor binding sites in the promoter region $(-222 /+450)$ of human amylin gene predicted with AliBaba2

\begin{tabular}{ll}
\hline Position per transcription factor & Sequence \\
\hline AP1 & \\
-214 to +208 & TGACACA \\
-141 to +135 & TGACCCA \\
-83 to +77 & TGACAGA \\
-59 to +53 & GATGTCA \\
+85 to +91 & TGACATT \\
NF- $\mathrm{kB}$ & \\
+123 to +133 & CTGGGAGAGTT \\
+246 to +256 & TTGGGAAAGTA \\
\hline
\end{tabular}

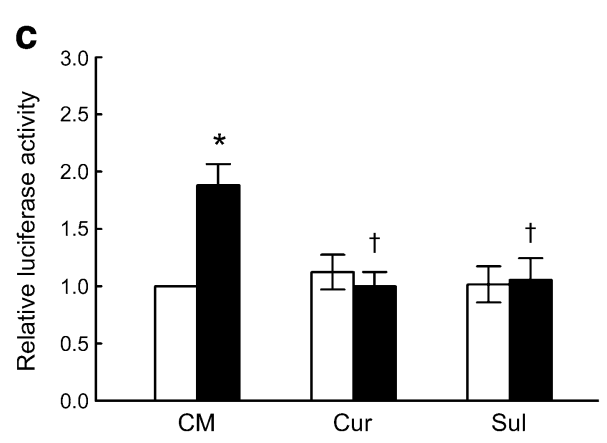

(Cur) or $500 \mu \mathrm{mol} / 1$ sulfalasazine (Sul), then stimulated for $8 \mathrm{~h}$ with $2.87 \mathrm{nmol} / \mathrm{l} \mathrm{TNF}-\alpha$ (black bars; control, white bars) and examined for luciferase activities. All data are shown as mean \pm SD of three independent experiments with each condition tested in triplicate. ${ }^{*} p<$ 0.05 for amylin promoter luciferase construct-transfected cells in response to TNF- $\alpha$ vs control medium; ${ }^{\dagger} p<0.05$ compared with cells treated with $2.87 \mathrm{nmol} / 1 \mathrm{TNF}-\alpha$ alone

KB pathways. There was no difference in AP1 activation by TNF- $\alpha$ between Nfkbia-DN plasmid-transfected cells and control vector-transfected cells (ESM Fig. 3), suggesting that $\mathrm{PI} 3 \mathrm{~K}-\mathrm{NF}-\mathrm{KB}$ and $\mathrm{PKC}_{\zeta}-\mathrm{JNK} / \mathrm{ERK} 1 / 2-\mathrm{AP} 1$ are two independent pathways involved in murine amylin upregulation by TNF- $\alpha$.

Our results demonstrated that AP1 and NF- $\mathrm{kB}$ not only mediated amylin upregulation by TNF- $\alpha$ in mouse pancreatic islets, but also participated in TNF- $\alpha$-induced human amylin promoter activation. While analysis with AliBaba2 revealed the existence of AP1 binding sites in the promoter regions of human and mouse amylin genes, NF- $\mathrm{KB}$ binding sites only exist in the promoter region of human amylin gene. Therefore, NF- $\mathrm{KB}$ activation may play an indirect role in murine amylin upregulation by TNF- $\alpha$. AP1 and $\mathrm{NF}-\mathrm{KB}$ are also the downstream signalling molecules of other proinflammatory cytokines. Our studies revealed that TNF- $\alpha$-induced murine amylin expression is independent of IL1 $\beta$, IL6 or monocyte chemoattractant protein 1,

Fig. 8 Proposed pathways for TNF- $\alpha$-induced amylin expression and production in mouse pancreatic beta cells. This overview is based on the present findings and does not exclude participation of other signalling pathways or complementary signals within the diagram presented

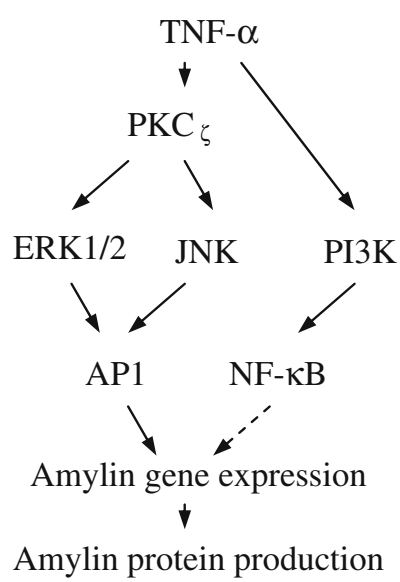


suggesting that TNF- $\alpha$ signalling directly activates AP1 and NF-KB to promote amylin expression. $\mathrm{Ca}^{2+}$ and pancreatic and duodenal homeobox 1 (PDX-1) have been reported to be involved in the upregulation of amylin gene expression by other stimuli, such as glucose and NEFA $[20,38]$. Pretreatment of MIN6 cells with EGTA (an extracellular calcium chelator) or 1,2-bis(o-aminophenoxy) ethane- $N, N, N^{\prime}, N^{\prime}$-tetraacetic acid (BAPTA-AM) (an intracellular calcium chelator), or transfection of MIN6 cells with dominant-negative PDX-1 expression plasmid had no influence on amylin upregulation by TNF- $\alpha$ (data not shown), suggesting that $\mathrm{Ca}^{2+}$ and PDX-1 are not involved in TNF- $\alpha$-induced amylin expression.

Immunoreactivity for the $\mathrm{NH}_{2}$-terminal flanking region of proamylin has been found in islet amyloid deposits in pancreas from type 2 diabetic patients [39]. It has been proposed that impaired processing of proamylin may lead to hypersecretion of unprocessed or partially processed forms of proamylin that may have a higher tendency to aggregate than mature amylin [40]. It has been reported that chronic exposure to high concentrations of glucose upregulates $P c 1 / 3$ and $P c 2$ mRNA levels and increases cellular content of amylin precursors in murine beta cells [41, 42]. However, acute treatment with glucose induces prohormone convertase (PC)1/3 and PC2 production in MIN6 cells at the translational level, but not the transcriptional level [43]. Our results reveal that acute treatment with TNF- $\alpha$ also had no acute effect on $P c 1 / 3$ and $P c 2$ mRNA expressions in MIN6 cells. We found that glucose and TNF- $\alpha$ increased levels of proamylin and the intermediate form of amylin in murine islets. Although glucose acutely upregulated PC1/3 and PC2 at the translational level, the activity of these enzymes might not have increased accordingly, leading to the increase of amylin precursors. The disproportional increase between $\mathrm{PC} 1 / 3$ and $\mathrm{PC} 2$ activity and proamylin expression may also have applied to TNF- $\alpha$-induced increase of amylin precursors, but needs further investigation. Widespread amyloid depositions have been found in transplanted islets in type 1 diabetes patients and mouse models of type 1 diabetes [44, 45]. Increased plasma amylin has been reported as a sign of impaired beta cell function in type 1 diabetic patients after kidney and pancreas transplantation [7]. The state of systemic inflammation and the inflammatory mediators have been proposed as causal roles in islet transplantation failure [46]. Amylin upregulation by proinflammatory cytokine TNF- $\alpha$ might contribute to plasma amylin elevation and amyloid deposition. But the effect of TNF- $\alpha$ on human proamylin processing and amylin aggregation/deposition needs to be examined with murine islets transfected with human proamylin or transgenic mice expressing human proamylin in beta cells [47].

Taken together, our studies demonstrate that TNF- $\alpha$ acutely induces amylin gene expression in murine beta cells through pathways related to the $\mathrm{PKC}_{\zeta}-\mathrm{JNK}-\mathrm{AP} 1, \mathrm{PKC}_{\zeta}-$ ERK1/2-AP1 and PI3K-NF- $\mathrm{BB}$ signalling pathways. AP1 and NF- $\mathrm{KB}$ are also involved in upregulation of human amylin transcription. Our results and the available evidence suggest that in addition to direct involvement in inflammatory disorders and insulin resistance, TNF- $\alpha$ may play an important role in overexpression of amylin under acute inflammatory conditions.

Acknowledgements We thank R. Lin (McGill University, Montreal, QC, Canada) for providing plasmid Nfkbia-DN and control vector flagzeo, and M. Li (Sun Yat-sen University, Guangzhou, People's Republic of China) for providing plasmid c-Jun DN. This work was supported by research grants from: the National Basic Research Program of China (973 Program) (2011CB504002); the One Hundred Talents Program of Chinese Academy of Sciences; the Chief Scientist Program of Shanghai Institutes for Biological Sciences (SIBS2008006); Chinese Academy of Sciences; and the Science and Technology Commission of Shanghai Municipality (03JC14079, 04DZ14007).

Duality of interest The authors declare that there is no duality of interest associated with this manuscript.

\section{References}

1. Lutz TA (2010) Roles of amylin in satiation, adiposity and brain development. Forum Nutr 63:64-74

2. Cornish J, Naot D (2002) Amylin and adrenomedullin: novel regulators of bone growth. Curr Pharm Des 8:2009-2021

3. Lutz TA (2010) The role of amylin in the control of energy homeostasis. Am J Physiol Regul Integr Comp Physiol 298: R1475-R1484

4. Cooper GJ, Willis AC, Clark A, Turner RC, Sim RB, Reid KB (1987) Purification and characterization of a peptide from amyloid-rich pancreases of type 2 diabetic patients. Proc Natl Acad Sci USA 84:8628-8632

5. Westermark P, Wernstedt C, Wilander E, Hayden DW, O'Brien TD, Johnson KH (1987) Amyloid fibrils in human insulinoma and islets of Langerhans of the diabetic cat are derived from a neuropeptide-like protein also present in normal islet cells. Proc Natl Acad Sci USA 84:3881-3885

6. Phillips AR, Abu-Zidan FM, Bonham MJ, Cooper GJ, Windsor JA (2000) Amylin and severe acute pancreatitis. Pancreas 20: 105-106

7. Stadler M, Anderwald C, Karer T et al (2006) Increased plasma amylin in type 1 diabetic patients after kidney and pancreas transplantation: a sign of impaired beta-cell function? Diab Care 29:1031-1038

8. Eriksson J, Nakazato M, Miyazato M, Shiomi K, Matsukura S, Groop L (1992) Islet amyloid polypeptide plasma concentrations in individuals at increased risk of developing type 2 (non-insulindependent) diabetes mellitus. Diabetologia 35:291-293

9. Enoki S, Mitsukawa T, Takemura J et al (1992) Plasma islet amyloid polypeptide levels in obesity, impaired glucose tolerance and non-insulin-dependent diabetes mellitus. Diabetes Res Clin Pract 15:97-102

10. Reinehr T, de Sousa G, Niklowitz P, Roth CL (2007) Amylin and its relation to insulin and lipids in obese children before and after weight loss. Obesity 15:2006-2011

11. Huang HJ, Young AA, Koda JE, Tulp OL, Johnson MJ, Cooper GJ (1992) Hyperamylinemia, hyperinsulinemia, and insulin 
resistance in genetically obese LA/N-cp rats. Hypertension 19: I101-I109

12. Granger J, Remick D (2005) Acute pancreatitis: models, markers, and mediators. Shock 24(Suppl 1):45-51

13. Narang AS, Mahato RI (2006) Biological and biomaterial approaches for improved islet transplantation. Pharmacol Rev 58:194-243

14. Lee YH, Pratley RE (2005) The evolving role of inflammation in obesity and the metabolic syndrome. Curr Diab Rep 5:70-75

15. Lang CH, Dobrescu C, Bagby GJ (1992) Tumor necrosis factor impairs insulin action on peripheral glucose disposal and hepatic glucose output. Endocrinology 130:43-52

16. Cheung AT, Ree D, Kolls JK, Fuselier J, Coy DH, Bryer-Ash M (1998) An in vivo model for elucidation of the mechanism of tumor necrosis factor-alpha (TNF-alpha)-induced insulin resistance: evidence for differential regulation of insulin signaling by TNF-alpha. Endocrinology 139:4928-4935

17. Wang X, Xiao G, Zhang Y et al (2008) Regulation of Tcrb recombination ordering by c-Fos-dependent RAG deposition. Nat Immunol 9:794-801

18. Marzban L, Soukhatcheva G, Verchere CB (2005) Role of carboxypeptidase $\mathrm{E}$ in processing of pro-islet amyloid polypeptide in $\beta$-cells. Endocrinology 146:1808-1817

19. Wang O, Cai K, Pang S et al (2008) Mechanisms of glucoseinduced expression of pancreatic-derived factor in pancreatic betacells. Endocrinology 149:672-680

20. Qi D, Cai K, Wang O et al (2010) Fatty acids induce amylin expression and secretion by pancreatic $\beta$-cells. Am J Physiol Endocrinol Metab 298:E99-E107

21. Carty MD, Lillquist JS, Peshavaria M, Stein R, Soeller WC (1997) Identification of cis- and trans-active factors regulating human islet amyloid polypeptide gene expression in pancreatic beta-cells. J Biol Chem 272:11986-11993

22. Lu X, Ma L, Ruan L et al (2010) Resveratrol differentially modulates inflammatory responses of microglia and astrocytes. J Neuroinflammation 7:46

23. Kahn SE, D'Alessio DA, Schwartz MW et al (1990) Evidence of cosecretion of islet amyloid polypeptide and insulin by beta-cells. Diabetes 39:634-638

24. Marzban L, Trigo-Gonzalez G, Verchere CB (2005) Processing of pro-islet amyloid polypeptide in the constitutive and regulated secretory pathways of beta cells. Mol Endocrinol 19:2154-2163

25. Bradley JR (2008) TNF-mediated inflammatory disease. J Pathol 214:149-160

26. Bain J, Plater L, Elliott M et al (2007) The selectivity of protein kinase inhibitors: a further update. Biochem J 408:297-315

27. Hirai T, Chida K (2003) Protein kinase Czeta (PKCzeta): activation mechanisms and cellular functions. J Biochem 133:1-7

28. Young MR, Yang HS, Colburn NH (2003) Promising molecular targets for cancer prevention: AP-1, NF-kappa B and Pdcd4. Trends Mol Med 9:36-41

29. Ma C, Ying C, Yuan $Z$ et al (2007) dp5/HRK is a c-Jun target gene and required for apoptosis induced by potassium deprivation in cerebellar granule neurons. J Biol Chem 282: 30901-30909

30. Dhawan P, Singh AB, Ellis DL, Richmond A (2002) Constitutive activation of Akt/protein kinase B in melanoma leads to upregulation of nuclear factor-kappaB and tumor progression. Cancer Res 62:7335-7342
31. Weber CK, Liptay S, Wirth T, Adler G, Schmid RM (2000) Suppression of NF-kappaB activity by sulfasalazine is mediated by direct inhibition of IkappaB kinases alpha and beta. Gastroenterology 119:1209-1218

32. Zhao T, Yang L, Sun Q et al (2007) The NEMO adaptor bridges the nuclear factor-kappaB and interferon regulatory factor signaling pathways. Nat Immunol 8:592-600

33. Hahm ER, Cheon G, Lee J, Kim B, Park C, Yang CH (2002) New and known symmetrical curcumin derivatives inhibit the formation of Fos-Jun-DNA complex. Cancer Lett 184:89-96

34. Shepherd LM, Campbell SC, Macfarlane WM (2004) Transcriptional regulation of the IAPP gene in pancreatic beta-cells. Biochim Biophys Acta 1681:28-37

35. Moller DE (2000) Potential role of TNF-alpha in the pathogenesis of insulin resistance and type 2 diabetes. Trends Endocrinol Metab $11: 212-217$

36. Bottino R, Fernandez LA, Ricordi C et al (1998) Transplantation of allogeneic islets of Langerhans in the rat liver: effects of macrophage depletion on graft survival and microenvironment activation. Diabetes 47:316-323

37. Hanley S, Liu S, Lipsett M et al (2006) Tumor necrosis factoralpha production by human islets leads to postisolation cell death Transplantation 82:813-818

38. Macfarlane WM, Campbell SC, Elrick LJ et al (2000) Glucose regulates islet amyloid polypeptide gene transcription in a PDX1and calcium-dependent manner. J Biol Chem 275:15330-15335

39. Westermark P, Engström U, Westermark GT, Johnson KH, Permerth J, Betsholtz C (1989) Islet amyloid polypeptide (IAPP) and pro-IAPP immunoreactivity in human islets of Langerhans. Diabetes Res Clin Pract 7:219-226

40. Porte D Jr, Kahn SE (1989) Hyperproinsulinemia and amyloid in NIDDM. Clues to etiology of islet beta-cell dysfunction? Diabetes 38:1333-1336

41. Schuppin GT, Rhodes CJ (1996) Specific co-ordinated regulation of PC3 and PC2 gene expression with that of preproinsulin in insulin-producing beta TC3 cells. Biochem J 313:259-268

42. Hou X, Ling Z, Quartier E et al (1999) Prolonged exposure of pancreatic beta cells to raised glucose concentrations results in increased cellular content of islet amyloid polypeptide precursors. Diabetologia 42:188-194

43. Skelly RH, Schuppin GT, Ishihara H, Oka Y, Rhodes CJ (1996) Glucose-regulated translational control of proinsulin biosynthesis with that of the proinsulin endopeptidases PC2 and PC3 in the insulin-producing MIN6 cell line. Diabetes 45:37-43

44. Westermark GT, Westermark P, Berne C, Korsgren O (2008) Nordic Network for Clinical Islet Transplantation. Widespread amyloid deposition in transplanted human pancreatic islets. N Engl J Med 359:977-979

45. Udayasankar J, Kodama K, Hull RL et al (2009) Amyloid formation results in recurrence of hyperglycaemia following transplantation of human IAPP transgenic mouse islets. Diabetologia 52:145-153

46. Huang X, Moore DJ, Ketchum RJ et al (2008) Resolving the conundrum of islet transplantation by linking metabolic dysregulation, inflammation, and immune regulation. Endocr Rev 29:603-630

47. Verchere CB, D'Alessio DA, Palmiter RD et al (1996) Islet amyloid formation associated with hyperglycemia in transgenic mice with pancreatic beta cell expression of human islet amyloid polypeptide. Proc Natl Acad Sci USA 93:3492-3496 